\title{
Triple Nitrate Isotopes Indicate Differing Nitrate Source Contributions to Streams Across a Nitrogen Saturation Gradient
}

\author{
Lucy A. Rose, ${ }^{1 *}$ Emily M. Elliott, ${ }^{1}$ and Mary Beth Adams ${ }^{2}$
}

\begin{abstract}
${ }^{1}$ Department of Geology and Planetary Science, University of Pittsburgh, 4107 O'Hara Street, 200 Space Research and Coordination Center, Pittsburgh, Pennsylvania 15260, USA $;{ }^{2}$ Fernow Experimental Forest, USDA Forest Service, 180 Canfield Street, Morgantown, West Virginia 26505, USA
\end{abstract}

\begin{abstract}
Nitrogen (N) deposition affects forest biogeochemical cycles worldwide, often contributing to $\mathrm{N}$ saturation. Using long-term ( $>30$-year) records of stream nitrate $\left(\mathrm{NO}_{3}{ }^{-}\right)$concentrations at Fernow Experimental Forest (West Virginia, USA), we classified four watersheds into $\mathrm{N}$ saturation stages ranging from Stage 0 (N-limited) to Stage $3(\mathrm{~N}$ saturated). We quantified $\mathrm{NO}_{3}{ }^{-}$contributions from atmospheric and microbial sources using $\delta^{15} \mathrm{~N}$, $\delta^{18} \mathrm{O}$, and $\Delta^{17} \mathrm{O}$ of $\mathrm{NO}_{3}{ }^{-}$and characterized the concentrations and isotopes of $\mathrm{NO}_{3}{ }^{-}$in precipitation. Despite receiving identical atmospheric inputs, the proportions of atmospheric $\mathrm{NO}_{3}{ }^{-}$in streams averaged from 7 to $10 \%$ in the hardwood watersheds (stages 1, 2, and 3) and 54\% in the conifer watershed (Stage 0 ). This suggests that the hardwood watersheds may be less responsive to future reductions in $\mathrm{N}$ deposition than the conifer watershed, at least in the short term. As shown in other studies, atmospheric $\mathrm{NO}_{3}{ }^{-}$proportions were
\end{abstract}

higher during stormflow. Despite large proportions of atmospheric $\mathrm{NO}_{3}{ }^{-}$in the Stage 0 stream, total atmospheric $\mathrm{NO}_{3}{ }^{-}-\mathrm{N}$ flux from this watershed $\left(2.9 \mathrm{~g} \mathrm{ha}^{-1}\right)$ was lower than fluxes in the other watersheds (range $=117.8-338.5 \mathrm{~g} \mathrm{ha}^{-1}$ ). Seasonal patterns of $\delta^{15} \mathrm{~N}^{-\mathrm{NO}_{3}}{ }^{-}$in the hardwood watersheds suggest enrichment of the soil $\mathrm{NO}_{3}{ }^{-}$pool during the growing season due to plant uptake. In all watersheds, $\delta^{18} \mathrm{O}$-based mixing models over-estimated atmospheric $\mathrm{NO}_{3}{ }^{-}$contributions to streams by up to $12 \%$ compared to $\Delta^{17} \mathrm{O}$-based estimates. Our results highlight the importance of atmospheric deposition as a $\mathrm{NO}_{3}{ }^{-}$source in low-concentration streams and demonstrate the advantage of using $\Delta^{17} \mathrm{O}-\mathrm{NO}_{3}{ }^{-}$over $\delta^{18} \mathrm{O}-\mathrm{NO}_{3}{ }^{-}$for $\mathrm{NO}_{3}{ }^{-}$source apportionment.

Key words: nitrogen saturation; nitrogen deposition; nitrate isotopes; Fernow Experimental Forest; $\delta^{15} \mathrm{~N}-\mathrm{NO}_{3}{ }^{-} ; \delta^{18} \mathrm{O}_{-} \mathrm{NO}_{3}{ }^{-} ; \Delta^{17} \mathrm{O}-\mathrm{NO}_{3}{ }^{-}$.
Received 12 July 2014; accepted 1 May 2015

Author contributions Emily M. Elliott designed the study. Lucy A. Rose executed the field work and data analysis. Lucy A. Rose, Emily M. Elliott, and Mary Beth Adams collaborated on the preparation of the paper.

*Corresponding author; e-mail: lab125@pitt.edu

\section{INTRODUCTION}

Long-term elevated deposition of atmospheric nitrate $\left(\mathrm{NO}_{3}{ }^{-}\right)$and ammonium $\left(\mathrm{NH}_{4}{ }^{+}\right)$to forests can lead to nitrogen saturation (Peterjohn and others 1996; Gilliam and others 2001; Aber and others 2003), with ecosystem responses including increased nitrification rates (Peterjohn and others 
1996; Gilliam and others 2001; Lovett and Goodale 2011), decreased soil fertility (Adams and others 2007), and increased $\mathrm{NO}_{3}{ }^{-}$and base cation leaching from soils leading to soil acidification (Adams and others 2006; Fernandez and others 2010). Nitrate concentrations and fluxes in soil and stream waters have been previously used to assess the $\mathrm{N}$ saturation status of forested watersheds (Stoddard 1994; Peterjohn and others 1996; Aber and others 2003; Lovett and Goodale 2011). However, ecosystem responses to atmospheric deposition can vary depending on site factors such as land-use and disturbance histories, species composition, and hydrologic regime (Aber and others 2003; Adams and others 2014). When examined at the watershed scale, stream $\mathrm{NO}_{3}{ }^{-}$dynamics integrate myriad ecosystem processes; it is therefore important to understand the relative contributions of atmospheric and microbial sources to stream $\mathrm{NO}_{3}{ }^{-} \mathrm{ex}-$ port. As anthropogenic additions to the global $\mathrm{N}$ cycle will likely continue unabated for the foreseeable future (Galloway and others 2003), clarifying how post-depositional processes in forests influence the transport and fate of atmospheric $\mathrm{NO}_{3}{ }^{-}$is critical to understanding ecosystem responses to chronic $\mathrm{N}$ deposition and the development of $\mathrm{N}$ saturation.

Aber and others $(1989,1998)$ described a conceptual model of ecosystem $\mathrm{N}$ saturation consisting of four stages, ranging from $\mathrm{N}$-limited (Stage 0) to severely $\mathrm{N}$-saturated (Stage 3); increasing nitrification rates and long-term increases in stream $\mathrm{NO}_{3}{ }^{-}$concentrations are important indicators of $\mathrm{N}$ saturation status in this conceptual model. Although rigorous testing of the $\mathrm{N}$ saturation concept requires extensive characterization of ecosystem pools and fluxes (Lovett and Goodale 2011), longterm (that is, decadal) stream chemistry dynamics can provide a convenient framework for investigating ecosystem responses to atmospheric $\mathrm{NO}_{3}{ }^{-}$ deposition (Stoddard 1994). When coupled with stable isotope measurements of stream $\mathrm{NO}_{3}{ }^{-}\left(\delta^{15} \mathrm{~N}\right.$, $\delta^{18} \mathrm{O}$, and $\left.\Delta^{17} \mathrm{O}\right)$, the relative contributions of atmospheric and microbial sources to stream $\mathrm{NO}_{3}{ }^{-}$ across a range of $\mathrm{N}$ saturation stages can be elucidated.

Previous studies have used nitrogen and oxygen stable isotopes to track spatio-temporal changes in atmospheric and microbial $\mathrm{NO}_{3}{ }^{-}$pools and to differentiate between them (Durka and others 1994; Burns and Kendall 2002; Pardo and others 2004; Barnes and others 2008; Sebestyen and others 2008, 2014; Goodale and others 2009). For example, temporal patterns in $\delta^{15} \mathrm{~N}$ values in precipitation and stream $\mathrm{NO}_{3}{ }^{-}$have been used to identify
$\mathrm{NO}_{3}{ }^{-}$uptake in forests (Barnes and others 2008). Similarly, $\delta^{18} \mathrm{O}_{-} \mathrm{NO}_{3}{ }^{-}$values have been used to distinguish atmospheric and soil sources and to determine their relative contributions to ecosystem $\mathrm{NO}_{3}{ }^{-}$pools (Williard and others 2001; Pardo and others 2004; Goodale and others 2009; Sebestyen and others 2014). However, preferential uptake of lighter isotopes (for example, ${ }^{14} \mathrm{~N}$ and ${ }^{16} \mathrm{O}$ ) during biological processes such as denitrification can alter $\delta^{15} \mathrm{~N}$ and $\delta^{18} \mathrm{O}$ values of residual $\mathrm{NO}_{3}{ }^{-}$pools, leading to imprecise source apportionment in some cases (Michalski and others 2004; Riha and others 2014). Nitrate isotopic source signatures can also result from processes not dependent on mass; these mass-independent signatures-such as $\Delta^{17} \mathrm{O}-$ $\mathrm{NO}_{3}{ }^{-}$- are not fractionated by biological processes and therefore serve as conservative tracers of atmospheric and microbial $\mathrm{NO}_{3}{ }^{-}$(Michalski and others 2004). Because atmospheric $\mathrm{NO}_{3}{ }^{-}$is characterized by positive $\Delta^{17} \mathrm{O}$ values and microbial $\mathrm{NO}_{3}{ }^{-}$by values of zero or less, $\Delta^{17} \mathrm{O}$ is a robust tool for quantifying the contributions of atmospheric and microbial $\mathrm{NO}_{3}{ }^{-}$to surface waters.

Nitrogen cycling is an important, but poorly understood phenomenon in forests, and the importance of atmospheric deposition in determining $\mathrm{N}$ exports is still not well elucidated. In this study, we quantified atmospheric and microbial source contributions to stream $\mathrm{NO}_{3}{ }^{-}$using triple $\mathrm{NO}_{3}{ }^{-}$ isotopes $\left(\delta^{15} \mathrm{~N}, \delta^{18} \mathrm{O}\right.$, and $\left.\Delta^{17} \mathrm{O}\right)$ of precipitation and stream water in four nearly adjacent watersheds at Fernow Experimental Forest (Figure 1). These watersheds have historically received some of the highest rates of atmospheric $\mathrm{NO}_{3}{ }^{-}$deposition in the U.S. (Adams and others 2003). Despite receiving identical atmospheric $\mathrm{N}$ inputs, these watersheds demonstrate differing long-term (>30-year) patterns in stream $\mathrm{NO}_{3}{ }^{-}$concentrations due to differences in internal $\mathrm{N}$ retention (Figure 2). Such stream $\mathrm{NO}_{3}{ }^{-}$concentration dynamics are consistent with the progressive stages of watershed $\mathrm{N}$ saturation described by Stoddard (1994) and Aber and others $(1989,1998)$ and are likely influenced to some extent by differences in tree species composition among the watersheds. These decades-long differences in stream $\mathrm{NO}_{3}{ }^{-}$concentrations served as the framework for the $\mathrm{N}$ saturation gradient examined in this study. Using triple $\mathrm{NO}_{3}{ }^{-}$isotope analyses, our study objectives were to (1) characterize and quantify the source contributions to stream $\mathrm{NO}_{3}{ }^{-}$in watersheds receiving identical $\mathrm{N}$ deposition inputs but exhibiting long-term differences in stream $\mathrm{NO}_{3}{ }^{-}$ concentrations and (2) elucidate the roles of biological and hydrologic drivers in regulating atmospheric $\mathrm{NO}_{3}{ }^{-}$export. Based on the results of prior 
studies (for example, Durka and others (1994)), we hypothesized that watersheds with higher $\mathrm{N}$ saturation status would have greater proportions of atmospheric $\mathrm{NO}_{3}{ }^{-}$in stream water than those with lower $\mathrm{N}$ saturation status.

\section{MeTHODS}

\section{Study Site}

Fernow Experimental Forest is located in West Virginia, on the unglaciated Allegheny Plateau (Figure 1). Elevations in the study watersheds range from 720 to $865 \mathrm{~m}$, and slopes average about $20 \%$. Bedrock is composed of hard sandstone and softer shale; little water storage occurs in these strata (Reinhart and others 1963; Kochenderfer 2007). Soils are well-drained silt loams of the Calvin series (loamy-skeletal, mixed active, mesic typic Dystrudept), averaging $1 \mathrm{~m}$ in depth (Kochenderfer 2007). Infiltration rates are high and most precipitation reaches the streams via subsurface flow (Reinhart and others 1963). During highintensity rain events, runoff is high and falls off quickly during periods of low-intensity or no pre- cipitation (Reinhart and others 1963). The growing season extends from late April through October and precipitation is evenly distributed throughout the year, averaging $1450 \mathrm{~mm}$; significant snowpack does not accumulate over long periods. Mixed hardwoods are the dominant forest type at Fernow, with northern red oak (Quercus rubra), sugar maple (Acer saccharum), red maple (Acer rubrum), black cherry (Prunus serotina), and yellow poplar (Liriodendron tulipifera), the most abundant species. As an exception to these native hardwoods, one research watershed was planted to Norway spruce (Picea abies) monoculture in 1973.

The research watersheds for this study were selected based on long-term (>30-year) differences in patterns of mean stream $\mathrm{NO}_{3}{ }^{-}-\mathrm{N}$ concentrations (Figure 2); these long-term differences were used to classify the watersheds into different $\mathrm{N}$ saturation stages, ranging from Stage 0 (N-limited) to Stage 3 (severely $\mathrm{N}$-saturated), following the conceptual model of $\mathrm{N}$ saturation described by Aber and others (1989). We sampled three mixed hardwood-dominated watersheds (Stages 1, 2, and 3) and one conifer-dominated watershed (Norway

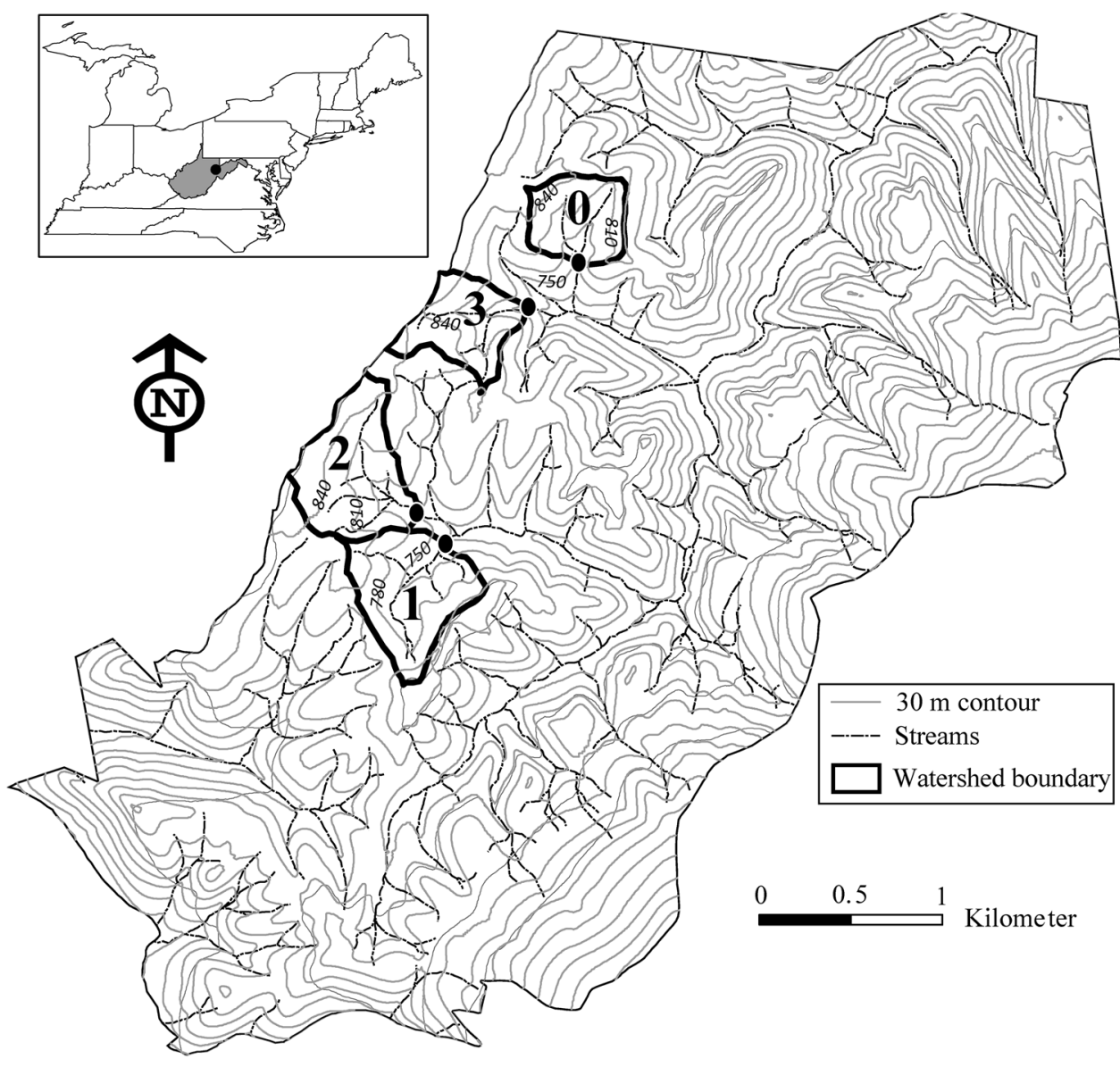

Figure 1. Map of study watersheds within the larger boundary of Fernow Experimental Forest (FEF). Numbers indicate $\mathrm{N}$ saturation stage; black dots show weir locations in study watersheds. Contour spacing is $30 \mathrm{~m}$. Inset shows the location of FEF (black dot) in the state of West Virginia (shown in grey). 


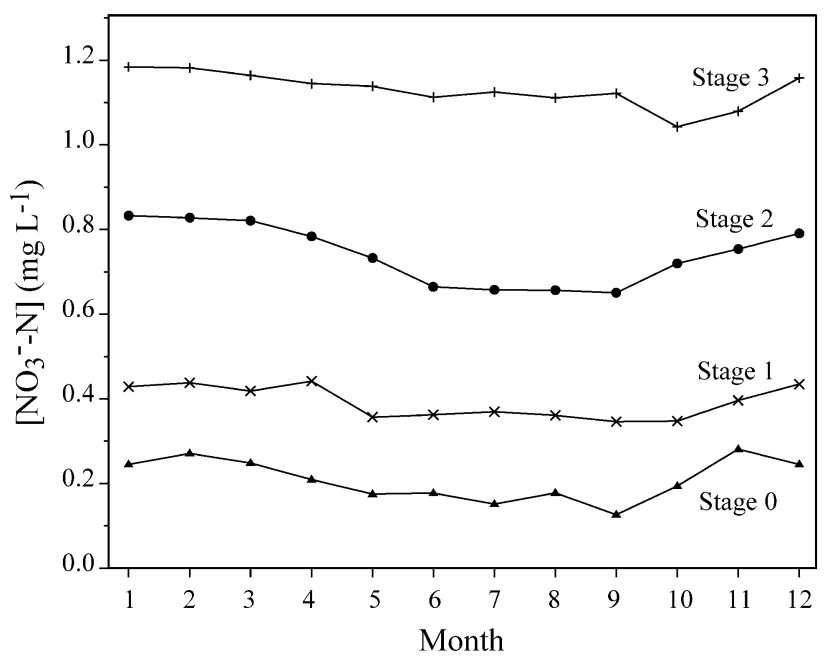

Figure 2. Monthly stream $\mathrm{NO}_{3}{ }^{-}-\mathrm{N}$ concentrations in the study watersheds at Fernow Experimental Forest averaged from weekly measurements collected from 1983 to 2007. The four watersheds exhibit differing long-term concentrations and seasonal patterns of $\mathrm{NO}_{3}{ }^{-}-\mathrm{N}$ in streams; watershed $\mathrm{N}$ saturation stage classification was based on these long-term differences in stream $\mathrm{NO}_{3}{ }^{-}-\mathrm{N}$ dynamics.

spruce; Stage 0) for this study. Several site characteristics are similar among the watersheds (for example atmospheric deposition inputs, climate, discharge patterns, geology, soils, elevation) but the watersheds differ with respect to a number of factors including stream $\mathrm{NO}_{3}{ }^{-}-\mathrm{N}$ concentrations, mean streambed and watershed slope, land-use history, and dominant overstory composition (Table 1). In addition, the riparian zone in the coniferdominated Stage 0 watershed is characterized by patches of Sphagnum sp. in some areas; such features are absent in any of the hardwood-dominated study watersheds. The presence of Sphagnum sp. patches in the Stage 0 watershed suggests that riparian wetland areas may be starting to form (Tiner 1993).

\section{Sample Collection}

From January through December 2010, 1 L stream samples were collected in acid-washed HDPE bottles from the stream just above a $120^{\circ} \mathrm{V}$-notch weir at the base of each watershed. Samples were collected on a weekly basis when streams were flowing. Samples were vacuum-filtered through $0.22 \mu \mathrm{m}$ polyethersulfone membrane filters to remove suspended solids and biological material. All samples were processed at the US Forest Service Timber and Watershed Laboratory in Parsons, West Virginia within $24 \mathrm{~h}$ of collection. Filtered samples were frozen and transported to the University of Pittsburgh, where they remained frozen until isotopic analysis. Weekly samples of wet-only depo- sition were collected at a National Atmospheric Deposition Program (NADP) National Trends Network site approximately $2 \mathrm{~km}$ from the study watersheds from February through December 2010. These samples were filtered through $0.45 \mu \mathrm{m}$ polyethersulfone membrane filters and archived at $4^{\circ} \mathrm{C}$ at the NADP Central Analytical Laboratory in Champaign, IL, USA. Precipitation samples were shipped to the University of Pittsburgh and frozen until isotopic analysis.

\section{Isotopic Analysis}

Nitrate concentrations were measured by ion chromatography (Dionex ICS-2000) at the University of Pittsburgh. For isotopic analysis, a denitrifying bacteria, Pseudomonas aureofaciens, was used to convert aqueous $\mathrm{NO}_{3}{ }^{-}$into gaseous $\mathrm{N}_{2} \mathrm{O}$ which was introduced into the mass spectrometer (Sigman and others 2001; Casciotti and others 2002). For $\Delta^{17} \mathrm{O}$ analysis, this $\mathrm{N}_{2} \mathrm{O}$ was thermally decomposed at $800^{\circ} \mathrm{C}$ into $\mathrm{N}_{2}$ and $\mathrm{O}_{2}$ prior to isotopic analysis following the method described by Kaiser and others (2007). Duplicate samples were analyzed for $\delta^{15} \mathrm{~N}$ and $\delta^{18} \mathrm{O}-\mathrm{NO}_{3}{ }^{-}$(and separately for $\Delta^{17} \mathrm{O}-\mathrm{NO}_{3}{ }^{-}$) on an Isoprime Trace Gas and Gilson GX-271 autosampler coupled with an Isoprime Continuous Flow Isotope Ratio Mass Spectrometer (CF-IRMS) at the Regional Stable Isotope Laboratory for Earth and Environmental Science Research at the University of Pittsburgh. Isotope values are reported in parts per thousand relative to $\mathrm{NO}_{3}{ }^{-}$ standards as follows: 


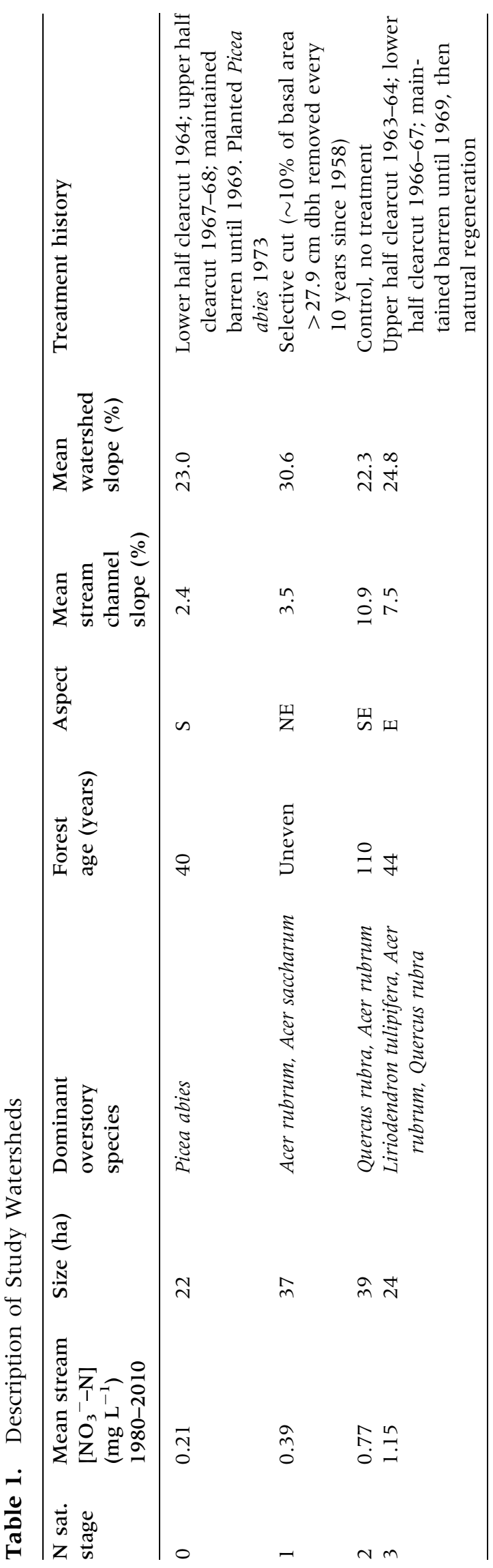

$\delta^{15} \mathrm{~N}, \delta^{18} \mathrm{O}, \quad$ and $\quad \delta^{17} \mathrm{O}(\% \mathrm{o})=\left[\left(\frac{R_{\text {sample }}}{R_{\text {standard }}}\right)-1\right] \times 1000$

where $R={ }^{15} \mathrm{~N} /{ }^{14} \mathrm{~N},{ }^{18} \mathrm{O} /{ }^{16} \mathrm{O}$, or ${ }^{17} \mathrm{O} /{ }^{16} \mathrm{O}$. The massindependent oxygen isotope anomaly $\left(\Delta^{17} \mathrm{O}-\right.$ $\mathrm{NO}_{3}{ }^{-}$) is likewise reported in parts per thousand and calculated using the equation:

$$
\Delta^{17} \mathrm{O}(\%)=\delta^{17} \mathrm{O}-0.52 \times \delta^{18} \mathrm{O}
$$

Samples with low $\mathrm{NO}_{3}{ }^{-}$concentrations were pre-concentrated prior to bacterial conversion to $\mathrm{N}_{2} \mathrm{O}$. For pre-concentration, we calculated the sample volume necessary to obtain a final $\mathrm{NO}_{3}{ }^{-}$ concentration of $20 \mathrm{nmol}$ (for $\delta^{15} \mathrm{~N}$ and $\delta^{18} \mathrm{O}$ analysis) or $200 \mathrm{nmol}$ (for $\Delta^{17} \mathrm{O}$ analysis) in a $5 \mathrm{ml}$ sample. Appropriate sample volumes were measured into $10 \%$ hydrochloric acid-washed Pyrex or Teflon beakers and placed in a drying oven at $60^{\circ} \mathrm{C}$ until all liquid was evaporated. The interior of each beaker was then rinsed with $10 \mathrm{ml}$ of $18 \mathrm{M} \Omega$ water to reconstitute duplicate samples to the appropriate concentration. Samples were prepared for isotopic analysis following the bacterial denitrifier method as previously described. International reference standards were similarly pre-concentrated for correction of pre-concentrated samples.

$\delta^{15} \mathrm{~N}$ and $\delta^{18} \mathrm{O}$ values were corrected using international reference standards USGS-32, USGS34, USGS-35, and IAEA-N3; USGS-34 and USGS35 were used to correct $\Delta^{17} \mathrm{O}$ values. These standards were also used to correct for linearity and instrument drift. Standard deviations for international reference standards were $0.2,0.5$, and $0.2 \%$ for $\delta^{15} \mathrm{~N}, \delta^{18} \mathrm{O}$, and $\Delta^{17} \mathrm{O}$, respectively.

$\delta^{15} \mathrm{~N}-\mathrm{NO}_{3}{ }^{-}$values must be corrected for interference from contributions of ${ }^{14} \mathrm{~N}^{14} \mathrm{~N}{ }^{17} \mathrm{O}$ to $\mathrm{m} / \mathrm{z} 45$ (Coplen and others 2004). These contributions were evaluated following the relationship described in Coplen and others (2004), where a $1 \%$ increase in $\delta^{15} \mathrm{~N}$ corresponds to an $18.8 \%$ increase in $\Delta^{17} \mathrm{O}$. Corrected $\delta^{15} \mathrm{~N}$ values in stream samples were zero to $1.3 \%$ (mean $=0.02 \%$ ) lower than uncorrected values, depending on the mass-independent contribution of $\Delta^{17} \mathrm{O}$ in the sample. Because $\Delta^{17} \mathrm{O}-\mathrm{NO}_{3}{ }^{-}$ values were low in most samples and because we could not apply the correction to some samples due to a lack of $\Delta^{17} \mathrm{O}$ data (particularly in the Stage 0 watershed), the $\delta^{15} \mathrm{~N}$ values presented here do not include the mass-independent $\Delta^{17} \mathrm{O}$ correction. Although interference-corrected $\delta^{15} \mathrm{~N}$ data are slightly lower than those presented here, the temporal and spatial patterns in $\delta^{15} \mathrm{~N}$ should not be strongly influenced by the omission of this correction. 


\section{End-Member Mixing Analysis}

We used a two-end-member isotope mixing model approach (using both $\delta^{18} \mathrm{O}$ and $\Delta^{17} \mathrm{O}$ isotope systems) to calculate the fraction of atmospheric $\mathrm{NO}_{3}{ }^{-}$ exported from each watershed (equation (3)):

$$
f_{\text {atm }}=\frac{\chi_{\text {stream }}-\chi_{\text {nitrification }}}{\chi_{\text {atm }}-\chi_{\text {nitrification }}}
$$

where $\chi$ is $\delta^{18} \mathrm{O}$ or $\Delta^{17} \mathrm{O}$ of $\mathrm{NO}_{3}{ }^{-}$. We used the lowest measured stream $\mathrm{NO}_{3}{ }^{-} \delta^{18} \mathrm{O}$ (or $\Delta^{17} \mathrm{O}$ ) value in each watershed as the nitrification endmember (Barnes and others 2008). The lowest $\Delta{ }^{17} \mathrm{O}-\mathrm{NO}_{3}{ }^{-}$values in the hardwood watersheds were $-1.2,-1.2$, and $-1.4 \%$ in the Stage 1,2 , and 3 watersheds, respectively. In the Stage 0 watershed, a value of zero was used for the nitrification end-member $\Delta^{17} \mathrm{O}$ value, as all stream samples had positive values. For the atmospheric end-member, we used the volume-weighted mean $\delta^{18} \mathrm{O}$ (or $\left.\Delta \Delta^{17} \mathrm{O}\right)$ value of all weekly precipitation samples collected during 2010. We used the volumeweighted mean rather than individual precipitation samples collected at the same time as stream samples because hydrologic transit times have not been characterized for most of the study watersheds, and the isotopic composition of atmospheric $\mathrm{NO}_{3}{ }^{-}$in a stream sample is unlikely to correspond to that of the precipitation sample collected during the same week.

\section{Nitrate Flux Calculation}

Nitrate-N fluxes were calculated in each watershed on a weekly basis using total weekly discharge (based on continuous flow level measurements taken at the weir) and $\mathrm{NO}_{3}{ }^{-} \mathrm{N}$ concentrations determined from stream samples collected weekly. Total annual $\mathrm{NO}_{3}{ }^{-}-\mathrm{N}$ flux in each watershed was calculated as the sum of all weekly $\mathrm{NO}_{3}{ }^{-}-\mathrm{N}$ fluxes during the study period. Total annual atmospheric $\mathrm{NO}_{3}{ }^{-}-\mathrm{N}$ fluxes were calculated for the entire study period by multiplying the total annual $\mathrm{NO}_{3}{ }^{-}-\mathrm{N}$ flux in each watershed by the discharge-weighted mean proportion of atmospheric $\mathrm{NO}_{3}{ }^{-}$in the stream (based on $\Delta^{17} \mathrm{O}-\mathrm{NO}_{3}{ }^{-}$). As the proportion of atmospheric $\mathrm{NO}_{3}{ }^{-}$in the Stage 0 watershed was based on only those stream samples with $\mathrm{NO}_{3}{ }^{-}-\mathrm{N}$ concentrations sufficient for $\Delta^{17} \mathrm{O}-\mathrm{NO}_{3}{ }^{-}$analysis $(n=4)$, the total atmospheric $\mathrm{NO}_{3}{ }^{-}-\mathrm{N}$ flux calculated for this watershed should be interpreted with caution.

\section{Statistical Analysis}

We used analysis of variance (ANOVA) to test for significant differences among watersheds. When significant differences were indicated, we applied Tukey's Honestly Significant Difference test to determine which means were significantly different $(\alpha=0.05)$. The experiment-wise error rate was held at $\alpha=0.05$ for comparisons among watersheds. To test for differences between growing season (May-October) and dormant season (November-April) means within individual watersheds, we used repeated measures ANOVA. All statistical analyses were conducted using volumeweighted concentrations and concentrationweighted isotope values; therefore, all means are reported as weighted values. In order to include samples with $\mathrm{NO}_{3}{ }^{-}$concentrations below the instrument detection limit $\left(0.01 \mathrm{mg} \mathrm{NO}_{3}{ }^{-} \mathrm{L}^{-1}\right)$ in statistical analyses, $\mathrm{NO}_{3}{ }^{-}$concentrations for these samples were set at $0.005 \mathrm{mg} \mathrm{NO}_{3}{ }^{-} \mathrm{L}^{-1}$ (one-half of the instrument detection limit). All statistical analyses were conducted using SAS statistical software (SAS Institute, Inc. 2011).

\section{Results}

\section{Nitrate-N Concentration}

Intermittent streamflow in all study watersheds prevented sample collection during parts of July through October in the Stage 0, 1, and 2 watersheds, and August through October in the Stage 3 watershed. In addition, low stream $\mathrm{NO}_{3}{ }^{-}-\mathrm{N}$ concentrations in the Stage 0 watershed precluded isotopic analysis of several samples. Stream $\mathrm{NO}_{3}{ }^{-}$ $\mathrm{N}$ concentrations across all watersheds ranged from below the instrument detection limit to $1.91 \mathrm{mg} \mathrm{L}^{-1}$ and precipitation $\mathrm{NO}_{3}{ }^{-}-\mathrm{N}$ concentrations ranged from 0.02 to $0.67 \mathrm{mg} \mathrm{L}^{-1}$ (Figure 3; Table 2). Mean $\mathrm{NO}_{3}{ }^{-}-\mathrm{N}$ concentrations were significantly different in all watersheds $(P<0.01$; Table 2$)$; this was expected, given the long-term patterns in stream $\mathrm{NO}_{3}{ }^{-}-\mathrm{N}$ concentrations in these watersheds (Figure 2) and the nature of the study design (that is, stream $\mathrm{NO}_{3}{ }^{-}$concentrations were used to define watershed $\mathrm{N}$ saturation status). The Stage 1, 2, and 3 (hardwood) watersheds showed significant seasonal differences in stream $\mathrm{NO}_{3}{ }^{-}-\mathrm{N}$ concentrations, with lower mean values during the growing season (May to October) than the dormant season (November to April) $(P<0.01$; Table 3$)$. 


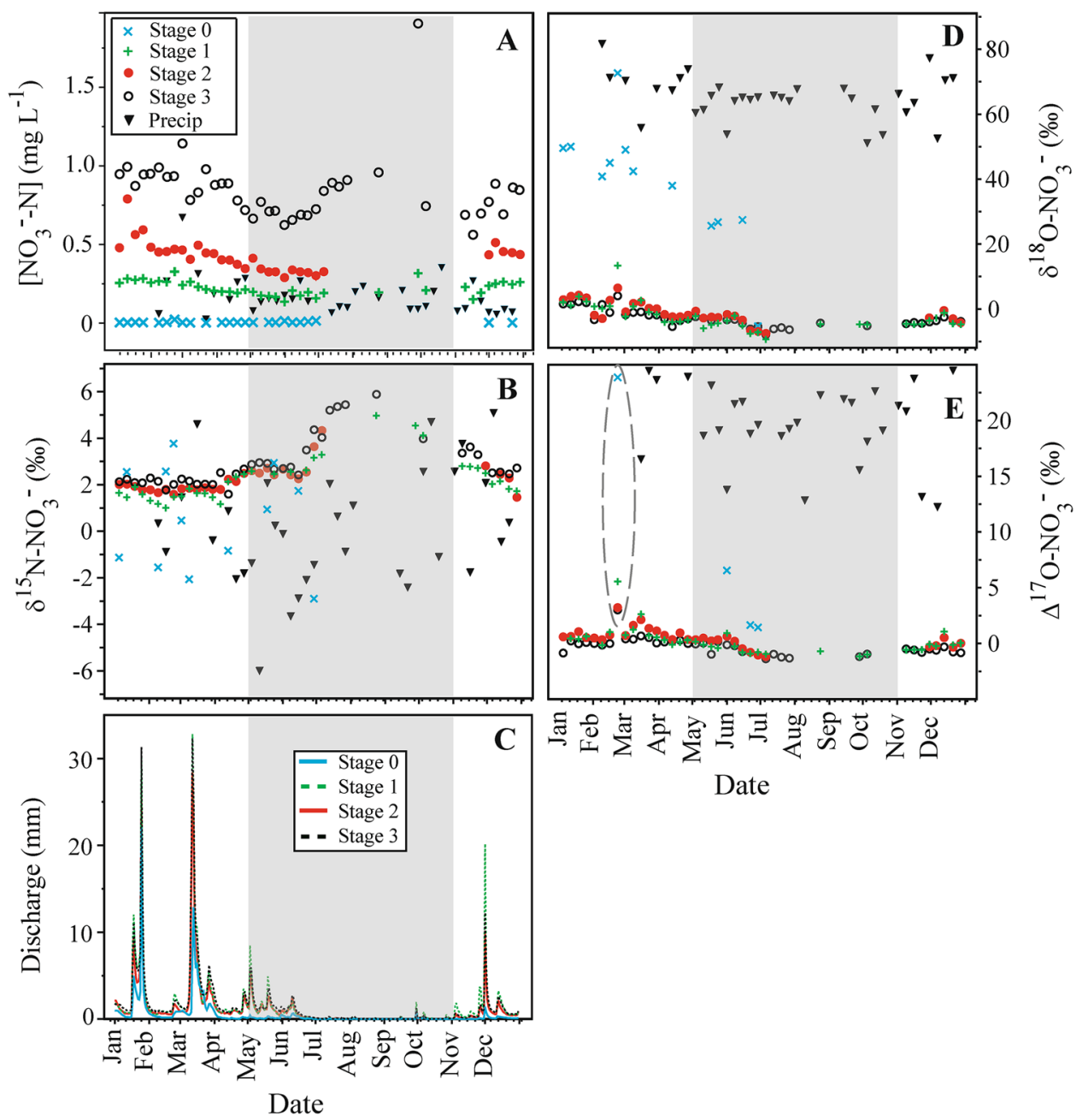

Figure 3. A Nitrate- $\mathrm{N}$ concentration, $\mathrm{B} \delta^{15} \mathrm{~N}-\mathrm{NO}_{3}{ }^{-}$, C Daily total discharge, $\mathrm{D} \delta^{18} \mathrm{O}-\mathrm{NO}_{3}{ }^{-}$, and $\mathrm{E} \Delta^{17} \mathrm{O}-\mathrm{NO}_{3}{ }^{-}$of weekly stream and precipitation samples collected at Fernow during 2010. Months shaded in grey represent the growing season. The dashed circle in E indicates samples collected during the snowmelt event on 23 February.

\section{$\delta^{15} \mathrm{~N}$ of Nitrate}

Across all watersheds, values of $\delta^{15} \mathrm{~N}$ in stream $\mathrm{NO}_{3}{ }^{-}$ranged from $-2.9 \%$ to $+5.9 \%$, and precipitation values ranged from $-6.0 \%$ to $+5.1 \%$ (Figure 3; Table 2). Mean $\delta^{15} \mathrm{~N}-\mathrm{NO}_{3}{ }^{-}$values were not significantly different among the watersheds or precipitation (Table 2). Seasonally, mean stream

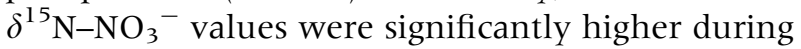
the growing season than the dormant season in the Stage 1, 2, and 3 watersheds $(P<0.01$; Table 3$)$. The seasonal variability in $\delta^{15} \mathrm{~N}-\mathrm{NO}_{3}{ }^{-}$may have contributed to the lower mean $\delta^{15} \mathrm{~N}-\mathrm{NO}_{3}{ }^{-}$value in the Stage 0 watershed, as streamflow was absent in this watershed during most of the growing season (when $\delta^{15} \mathrm{~N}$ values were highest in the Stage 1, 2, and 3 watersheds; Figure 3). In contrast to the seasonal patterns in the hardwood watersheds, the mean $\delta^{15} \mathrm{~N}-\mathrm{NO}_{3}{ }^{-}$value in precipitation was lower during the growing season than the dormant season, but this difference was not statistically significant (Table 3).

\section{$\delta^{18} \mathrm{O}$ of Nitrate}

Across all watersheds, $\delta^{18} \mathrm{O}$ values in stream $\mathrm{NO}_{3}{ }^{-}$ ranged from -9.4 to $+72.8 \%$, whereas precipita-

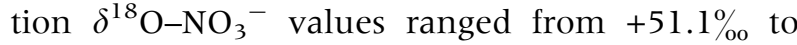
$+81.7 \%$ (Figure 3; Table 2). The highest mean $\delta^{18} \mathrm{O}-\mathrm{NO}_{3}{ }^{-}$value of stream $\mathrm{NO}_{3}{ }^{-}$occurred in the Stage 0 watershed $(+40.4 \%$; Table 2$)$. This mean was significantly higher than those in all other watersheds, but significantly lower than the mean precipitation $\delta^{18} \mathrm{O}_{-} \mathrm{NO}_{3}{ }^{-} \quad$ value $\quad(+65.3 \%)$ $(P<0.01$ for all comparisons). In all watersheds and in precipitation, mean $\delta^{18} \mathrm{O}-\mathrm{NO}_{3}{ }^{-}$values were significantly higher during the dormant season than the growing season $(P<0.02$; Table 3$)$. 


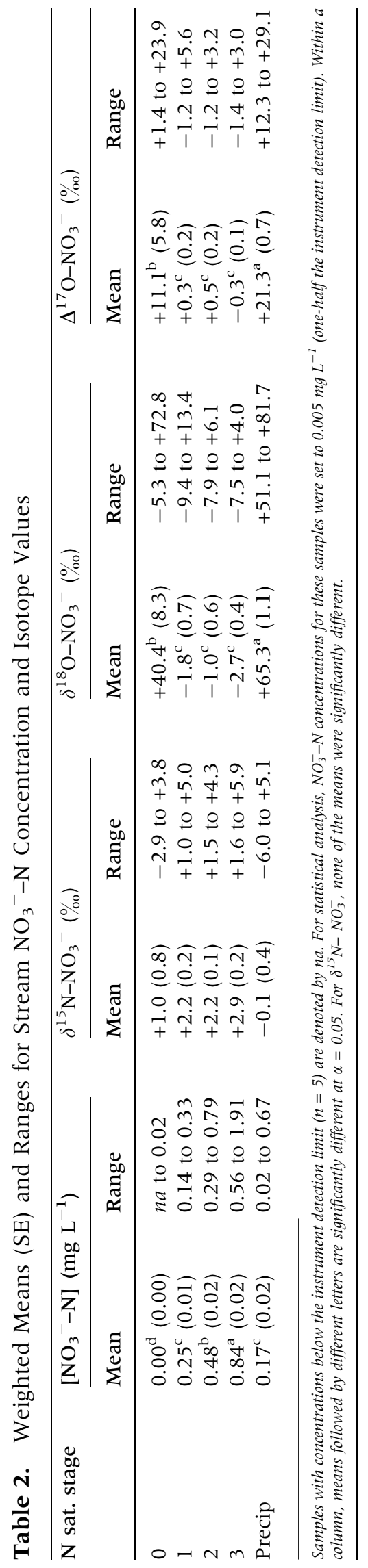

\section{$\Delta^{17} \mathrm{O}$ of Nitrate}

$\Delta^{17} \mathrm{O}-\mathrm{NO}_{3}{ }^{-}$values in stream water ranged from $-1.4 \%$ to $+23.9 \%$ across all watersheds (Figure 3; Table 2), with a significantly higher mean value in the Stage 0 watershed than in the other watersheds $(P<0.01$ for all comparisons; Table 2). However, mean stream $\Delta^{17} \mathrm{O}-\mathrm{NO}_{3}{ }^{-}$values were not significantly different when ANOVA was conducted using only data for the four dates on which $\Delta^{17} \mathrm{O}$ values were available in the Stage 0 watershed (in other words, $n=4$ for each watershed). While this analysis allows for a more balanced comparison of $\Delta \Delta^{17} \mathrm{O}$ values across watersheds, the small sample sizes weaken the statistical power of ANOVA, making it difficult to discern whether the mean $\Delta{ }^{17} \mathrm{O}$ value in the Stage 0 watershed is truly different from the others. Precipitation $\Delta^{17} \mathrm{O}-\mathrm{NO}_{3}{ }^{-}$ values ranged from +12.3 to $+29.1 \%$, with a mean of $+20.6 \%$. Mean $\Delta^{17} \mathrm{O}-\mathrm{NO}_{3}{ }^{-}$values in the Stage 1 and 2 watersheds and in precipitation were significantly higher during the dormant season than the growing season $(P<0.04$; Table 3$)$. In the Stage 0 and 3 watersheds, mean $\Delta^{17} \mathrm{O}-\mathrm{NO}_{3}{ }^{-}$values were also higher during the dormant season than the growing season, but seasonal differences were not statistically significant. In all watersheds, the highest $\Delta^{17} \mathrm{O}_{-} \mathrm{NO}_{3}{ }^{-}$value measured during 2010 occurred on 23 February, coincident with a snowmelt event (Figure 3).

\section{Proportions and Fluxes of Atmospheric Nitrate in Streams}

We calculated the proportions of atmospheric $\mathrm{NO}_{3}{ }^{-}$ in streams using both $\delta^{18} \mathrm{O}-\mathrm{NO}_{3}{ }^{-}$and $\Delta^{17} \mathrm{O}-\mathrm{NO}_{3}{ }^{-}$ values to evaluate differences in estimated atmospheric $\mathrm{NO}_{3}{ }^{-}$proportions in streams. Substituting $\delta^{18} \mathrm{O}_{-} \mathrm{NO}_{3}{ }^{-}$values into equation (3), the mean proportions of atmospheric $\mathrm{NO}_{3}{ }^{-}$in the Stage 0,1 , 2 , and 3 watersheds were $76,14,12$, and $9 \%$, respectively. When $\Delta^{17} \mathrm{O}-\mathrm{NO}_{3}{ }^{-}$values were substituted into equation (3), mean proportions of atmospheric $\mathrm{NO}_{3}{ }^{-}$were $54,9,10$, and $7 \%$ in the Stage $0,1,2$, and 3 watersheds, respectively. The $\Delta{ }^{17} \mathrm{O}$-based estimate for the Stage 0 watershed $(54 \%)$ should be interpreted with caution, as samples collected on only four dates during 2010 had adequate $\mathrm{NO}_{3}{ }^{-}-\mathrm{N}$ concentrations for $\Delta^{17} \mathrm{O}-$ $\mathrm{NO}_{3}{ }^{-}$analysis (for comparison, mean proportions of atmospheric $\mathrm{NO}_{3}{ }^{-}$in the Stage 1,2 , and 3 watersheds calculated for these four sampling dates were 20,11 , and $10 \%$, respectively). This caveat notwithstanding, both $\delta^{18} \mathrm{O}$ - and $\Delta^{17} \mathrm{O}$-based estimates indicate that proportions of atmospheric 
Table 3. Weighted Means (SE) of Growing Season and Dormant Season $\mathrm{NO}_{3}{ }^{-}-\mathrm{N}$ Concentrations and Isotope Values

\begin{tabular}{|c|c|c|c|c|c|c|c|c|}
\hline \multirow[t]{2}{*}{ N Sat. Stage } & \multicolumn{2}{|c|}{$\left[\mathrm{NO}_{3}{ }^{-}-\mathrm{N}\right]\left(\mathrm{mg} \mathrm{L}^{-1}\right)$} & \multicolumn{2}{|c|}{$\delta^{15} \mathrm{~N}-\mathrm{NO}_{3}{ }^{-}(\%)$} & \multicolumn{2}{|c|}{$\delta^{18} \mathrm{O}-\mathrm{NO}_{3}{ }^{-}(\%)$} & \multicolumn{2}{|c|}{$\Delta^{17} \mathrm{O}-\mathrm{NO}_{3}{ }^{-}(\%)$} \\
\hline & Growing & Dormant & Growing & Dormant & Growing & Dormant & Growing & Dormant \\
\hline 0 & $0(0.00)$ & $0.00(0.00)$ & $0.6(1.2)$ & $+2.0(0.9)$ & $+10.3^{\mathrm{a}}(7.7)$ & $+58.3^{\mathrm{b}}(5.9)$ & $+3.3(1.7)$ & $+23.9 n a$ \\
\hline 1 & $0.20^{\mathrm{a}}(0.02)$ & $0.26^{\mathrm{b}}(0.01)$ & $+3.1^{\mathrm{a}}(0.2)$ & $+1.8^{\mathrm{b}}(0.1)$ & $-5.1^{\mathrm{a}}(1.2)$ & $-0.5^{\mathrm{b}}(0.7)$ & $-0.6^{\mathrm{a}}(0.4)$ & $+0.7^{\mathrm{b}}(0.3)$ \\
\hline 2 & $0.35^{\mathrm{a}}(0.04)$ & $0.50^{\mathrm{b}}(0.02)$ & $+2.7^{\mathrm{a}}(0.1)$ & $+1.9^{\mathrm{b}}(0.1)$ & $-4.0^{\mathrm{a}}(1.0)$ & $+0.1^{\mathrm{b}}(0.5)$ & $-0.1^{\mathrm{a}}(0.3)$ & $+0.8^{\mathrm{b}}(0.2)$ \\
\hline 3 & $0.71^{\mathrm{a}}(0.03)$ & $0.87^{\mathrm{b}}(0.02)$ & $+3.9^{\mathrm{a}}(0.2)$ & $+2.3^{\mathrm{b}}(0.2)$ & $-4.8^{\mathrm{a}}(0.6)$ & $-1.6^{\mathrm{b}}(0.4)$ & $-0.8(0.2)$ & $+0.1(0.1)$ \\
\hline Precip & $0.15(0.03)$ & $0.21(0.03)$ & $-0.7(0.6)$ & $+0.6(0.6)$ & $+62.5^{\mathrm{a}}(1.4)$ & $+68.0^{\mathrm{b}}(1.4)$ & $+19.4^{\mathrm{a}}(0.9)$ & $+23.6^{\mathrm{b}}(1.0)$ \\
\hline
\end{tabular}

Growing and dormant season means followed by different letters are significantly different at $\alpha=0.05$

na denotes that the standard error could not be calculated due to $n=1$.

$\mathrm{NO}_{3}{ }^{-}$in streams were much lower in the Stage 1, 2 , and 3 (hardwood) watersheds than in the Stage 0 (conifer) watershed, and mean proportions of atmospheric $\mathrm{NO}_{3}{ }^{-}$tended to decrease with increasing mean stream $\mathrm{NO}_{3}{ }^{-}-\mathrm{N}$ concentrations. For all watersheds, the mean proportions of atmospheric $\mathrm{NO}_{3}{ }^{-}$in streams estimated by $\delta^{18} \mathrm{O}-\mathrm{NO}_{3}{ }^{-}$ were greater than those based on $\Delta^{17} \mathrm{O}-\mathrm{NO}_{3}{ }^{-}$.

In contrast to the pattern of atmospheric $\mathrm{NO}_{3}{ }^{-}$ proportions in streams, total fluxes of atmospheric $\mathrm{NO}_{3}{ }^{-}-\mathrm{N}$ in streams increased with increasing mean $\mathrm{NO}_{3}{ }^{-}-\mathrm{N}$ concentration (Table 4 ). During the study period, total stream fluxes of atmospheric $\mathrm{NO}_{3}{ }^{-}-\mathrm{N}$ were $2.9,117.8,207.5$, and $338.5 \mathrm{~g} \mathrm{ha}^{-1}$ in the Stage $0,1,2$, and 3 watersheds, respectively (Table 4 ). These $\Delta^{17} \mathrm{O}$-based flux estimates do not account for contributions of atmospheric $\mathrm{NH}_{4}{ }^{+}$that may have been oxidized to $\mathrm{NO}_{3}{ }^{-}$prior to export from the watersheds. Therefore, these estimates represent only that fraction of total stream $\mathrm{N}$ export contributed directly from atmospheric $\mathrm{NO}_{3}{ }^{-}$. Total atmospheric $\mathrm{NO}_{3}{ }^{-}-\mathrm{N}$ deposition (wet + dry) at Fernow during 2010 was $3.28 \mathrm{~kg} \mathrm{ha}^{-1}$ and total inorganic $\mathrm{N}$ deposition (wet + dry $\mathrm{NO}_{3}{ }^{-}-\mathrm{N}$ and $\mathrm{NH}_{4}{ }^{+}-\mathrm{N}$ ) was $5.25 \mathrm{~kg} \mathrm{ha}^{-1}$ (U.S. Environmental Protection Agency 2014).

\section{Discussion}

\section{Biological and Hydrologic Influences on Stream Nitrate Sources and Export}

The patterns of atmospheric $\mathrm{NO}_{3}{ }^{-}$export from the study watersheds at Fernow contradict our initial hypothesis of increasing proportions of atmospheric $\mathrm{NO}_{3}{ }^{-}$in streams with increasing $\mathrm{N}$ saturation status. However, on a flux basis, atmospheric $\mathrm{NO}_{3}{ }^{-}$ contributions to streams increased with increasing $\mathrm{N}$ saturation stage, consistent with the results of Durka and others (1994) who observed the greatest atmospheric $\mathrm{NO}_{3}{ }^{-}$fluxes from forests in a deposition-induced state of decline. Our results also demonstrate a comparatively stronger response of microbial $\mathrm{NO}_{3}{ }^{-}$fluxes to increasing $\mathrm{N}$ saturation stage relative to atmospheric $\mathrm{NO}_{3}{ }^{-}$fluxes, suggesting that while the capacity for biological $\mathrm{N}$ cycling may not decrease with progressive $\mathrm{N}$ saturation, the capacity for $\mathrm{N}$ retention within watersheds can diminish.

The study watersheds at Fernow reflect important differences in biological and hydrologic ecosystem attributes. Perhaps the most obvious difference is that of the species composition in the Stage 0 watershed, the Norway spruce monoculture. Many previous studies have demonstrated the influence of species composition on soil characteristics related to $\mathrm{N}$ cycling and export (Buldgen and others 1983; Lovett and others 2002, 2004; Templer and others 2005; Kelly and others 2011; Prescott and Grayston 2013). The high $\Delta^{17} \mathrm{O}-\mathrm{NO}_{3}{ }^{-}$ values in the Stage 0 watershed indicate that atmospheric deposition is a more important source of stream $\mathrm{NO}_{3}{ }^{-}$than microbial nitrification in this conifer-dominated watershed. Although it is possible that the low stream $\mathrm{NO}_{3}{ }^{-}-\mathrm{N}$ concentrations and limited $\Delta^{17} \mathrm{O}-\mathrm{NO}_{3}{ }^{-}$data in the stage 0 watershed resulted in a biased estimate of atmospheric $\mathrm{NO}_{3}{ }^{-}$contributions in this stream, additional data support the observation that microbial nitrification constitutes a smaller proportion of total stream $\mathrm{NO}_{3}{ }^{-}$in the Stage 0 watershed than in the Stage 1, 2, and 3 watersheds. First, although $\delta^{18} \mathrm{O}$ is a less conservative tracer of atmospheric $\mathrm{NO}_{3}{ }^{-}$than $\Delta^{17} \mathrm{O}$ (Michalski and others 2004; Kendall and others 2007; Riha and others 2014), the larger dataset $(n=12)$ and high isotope values of $\delta^{18} \mathrm{O}-\mathrm{NO}_{3}{ }^{-}$in the Stage 0 watershed (median $=+41.7 \%$ o ) support the conclusion that atmospheric deposition is a major source of stream $\mathrm{NO}_{3}{ }^{-}$. Second, the mean A horizon $\mathrm{C}: \mathrm{N}$ in the 


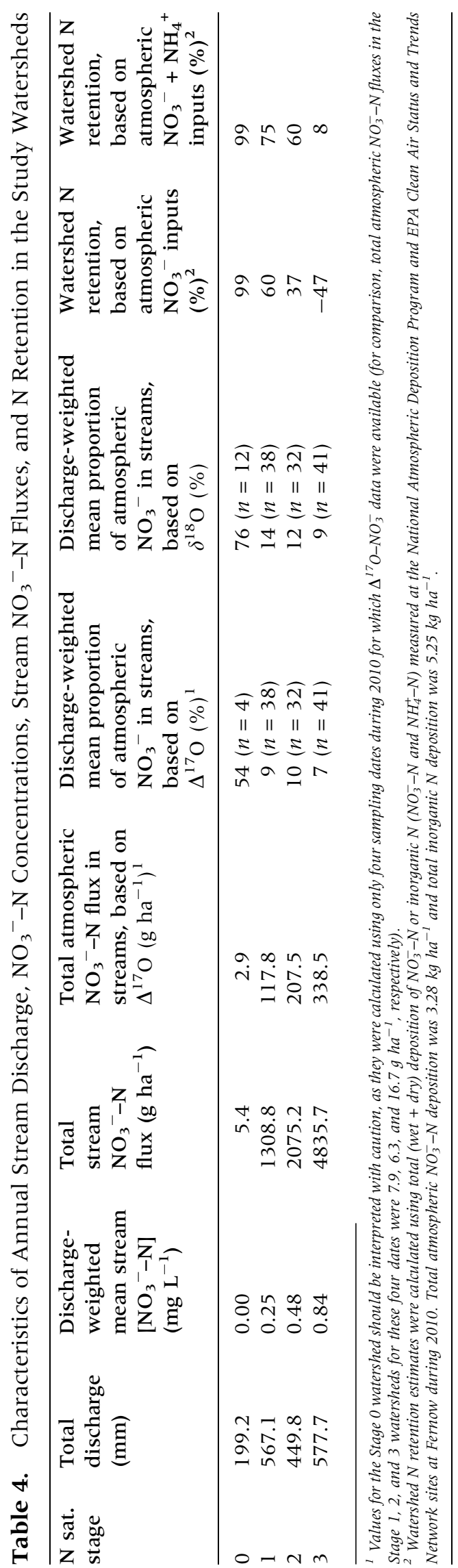

Stage 0 watershed is higher than that in the Stage 3 watershed (18 vs. 15 in the Stage 0 and 3 watersheds, respectively; (Kelly and others 2011)), and the Stage 2 watershed (mean $\mathrm{C}: \mathrm{N}=16$; Christ and others 2002). It is possible that A horizon C: $\mathrm{N}$ is more spatially variable in the Stage 2 and 3 watersheds due to greater species diversity in these mixed hardwood-dominated watersheds compared to the Norway spruce-dominated Stage 0 watershed, potentially influencing mineralization and nitrification rates (Lovett and others 2004). Typically, litter from conifer species is more recalcitrant (that is, higher $\mathrm{C}: \mathrm{N}$ and lignin:N) than litter from hardwood species such as maple and tulip poplar (Lovett and others 2004; Kelly 2010), and previous studies have demonstrated significant negative correlations between soil C:N and net nitrification rates (Christ and others 2002; Ross and others 2004; Christenson and others 2009; Kelly and others 2011). In the Stage 0 watershed, the mean annual net nitrification rate of $4.2 \mathrm{~kg} \mathrm{~N} \mathrm{ha}^{-1} \mathrm{y}^{-1}$ (Kelly 2010) is 27 times lower than the rates measured by Gilliam and others (2001) in the Stage 2 and 3 watersheds (114 and $115 \mathrm{~kg} \mathrm{~N} \mathrm{ha}^{-1} \mathrm{y}^{-1}$ respectively). This markedly lower rate of microbial $\mathrm{NO}_{3}{ }^{-}$production in the Stage 0 watershed contributes to both the low proportions of microbial $\mathrm{NO}_{3}{ }^{-}$in the stream and the low total $\mathrm{NO}_{3}{ }^{-}-\mathrm{N}$ flux from this watershed. The stream $\mathrm{NO}_{3}{ }^{-}$source dynamics observed in the study watersheds have important implications for our understanding of the ecosystem effects of $\mathrm{N}$ deposition. For example, the higher proportions of atmospheric $\mathrm{NO}_{3}{ }^{-}$in the Stage 0 stream suggest that this watershed might show the strongest immediate response to changing rates of atmospheric $\mathrm{N}$ deposition. In contrast, the overwhelming contributions of microbial $\mathrm{NO}_{3}{ }^{-}$to the Stage 1, 2, and 3 streams suggest that a reduction in rates of atmospheric $\mathrm{N}$ deposition to these watersheds might yield only minor immediate reductions in stream $\mathrm{NO}_{3}{ }^{-}$concentrations and fluxes. In the longer term, reductions in $\mathrm{N}$ deposition would likely reduce the level of $\mathrm{N}$ cycling and nitrification in these watersheds, resulting in a decline in the microbial fraction of exported $\mathrm{NO}_{3}{ }^{-}$.

Although the relative contributions of $\mathrm{NO}_{3}{ }^{-}$ from atmospheric and microbial sources influence stream $\mathrm{NO}_{3}{ }^{-}-\mathrm{N}$ concentrations and fluxes, watershed hydrologic status is an additional key driver of microbial and atmospheric $\mathrm{NO}_{3}{ }^{-}$export to streams (Creed and Band 1998; Adams and others 2014; Sebestyen and others 2014). In all of the study watersheds, $\delta^{18} \mathrm{O}-\mathrm{NO}_{3}{ }^{-}$and $\Delta^{17} \mathrm{O}-\mathrm{NO}_{3}{ }^{-}$values were generally higher in stream samples collected during stormflow, and both $\delta^{18} \mathrm{O}-\mathrm{NO}_{3}{ }^{-}$and $\Delta^{17} \mathrm{O}-$ 
$\mathrm{NO}_{3}{ }^{-}$were positively correlated with discharge $(P<0.05)$ (except $\Delta^{17} \mathrm{O}-\mathrm{NO}_{3}{ }^{-}$in the Stage 0 watershed, due to the limited $\Delta^{17} \mathrm{O}-\mathrm{NO}_{3}{ }^{-}$dataset in this watershed). In the Stage 1, 2, and 3 watersheds, 54 to $61 \%$ of total $\mathrm{NO}_{3}{ }^{-}$export and 62 to $77 \%$ of total atmospheric $\mathrm{NO}_{3}{ }^{-}$export during 2010 occurred on nine sampling dates, coincident with stormflow. This suggests that most of the total $\mathrm{NO}_{3}{ }^{-}$(and atmospheric $\mathrm{NO}_{3}{ }^{-}$in particular) that was exported from these watersheds during 2010 occurred during stormflow. The role of hydrologic drivers in regulating atmospheric $\mathrm{NO}_{3}{ }^{-}$export is further demonstrated by the high $\Delta^{17} \mathrm{O}-\mathrm{NO}_{3}{ }^{-}$values measured in all watersheds on 23 February, coincident with the rising limb of a snowmelt event. Using the highest precipitation $\Delta^{17} \mathrm{O}-\mathrm{NO}_{3}{ }^{-}$ value measured during the study period $(+29.1 \%$ o $)$ and the lowest $\Delta^{17} \mathrm{O}-\mathrm{NO}_{3}{ }^{-}$value measured in each watershed (and $0 \%$ for the Stage 0 watershed) for the nitrification end-member in equation (3), conservative estimates of atmospheric $\mathrm{NO}_{3}{ }^{-}$in streams were $82,22,15$, and $15 \%$ of total stream $\mathrm{NO}_{3}{ }^{-}$in the Stage $0,1,2$, and 3 watersheds, respectively, on 23 February. Rapid routing of melt water to streams and decreased biological activity during the winter could have facilitated elevated proportions of atmospheric $\mathrm{NO}_{3}{ }^{-}$in streams on this date. Several studies in forested watersheds have also reported elevated atmospheric $\mathrm{NO}_{3}{ }^{-}$contributions to streams during snowmelt (Burns and Kendall 2002; Sebestyen and others 2008; Goodale and others 2009; Pellerin and others 2012). That the largest proportions of atmospheric $\mathrm{NO}_{3}{ }^{-}$in all streams occurred on the same date suggests that a common factor (for example, hydrologic status) influenced atmospheric $\mathrm{NO}_{3}{ }^{-}$export from the study watersheds during this stormflow event. However, when examined over the entire study period, differing biogeochemical responses among some of the study watersheds indicate that hydrologic and biological drivers may interact to regulate $\mathrm{NO}_{3}{ }^{-}$export dynamics over longer temporal scales.

Although the lowest mean proportion of atmospheric $\mathrm{NO}_{3}{ }^{-}(7 \%)$ occurred in the Stage 3 watershed, total $\mathrm{NO}_{3}{ }^{-}-\mathrm{N}$ concentrations and discharge were highest in this watershed resulting in the greatest fluxes of both total and atmospheric $\mathrm{NO}_{3}{ }^{-}-$ $\mathrm{N}$ (Table 4). In contrast, the Stage 1 watershed had a slightly greater mean proportion of atmospheric $\mathrm{NO}_{3}{ }^{-}(9 \%)$ and nearly identical total annual discharge to that in the Stage 3 watershed, but total and atmospheric $\mathrm{NO}_{3}{ }^{-}-\mathrm{N}$ fluxes in the Stage 1 watershed were around 3 times less than those in the Stage 3 watershed. Thus, despite identical atmospheric deposition inputs and nearly identical patterns of discharge during the study period, these two watersheds exhibited differing total and atmospheric $\mathrm{NO}_{3}{ }^{-}$exports during 2010. The difference in $\mathrm{NO}_{3}{ }^{-}-\mathrm{N}$ fluxes indicates that retention of atmospheric $\mathrm{NO}_{3}{ }^{-}$in the Stage 1 watershed is greater than that in the Stage 3 watershed. This may be due to biological differences (for example, degree of $\mathrm{NO}_{3}{ }^{-}$retention in vegetation and soils, possibly due to lower nitrification rates in the Stage l watershed), hydrologic differences (for example, hydrologic transit times along flowpaths), or some combination of these (and possibly additional) factors. Although the predominant hydrologic source areas and flowpaths have not been characterized in these watersheds, we might expect the steeper slopes in the Stage 1 watershed (mean $=30.6 \%$ versus $24.8 \%$ in the Stage 3 watershed) to facilitate equal or greater fluxes of atmospheric $\mathrm{NO}_{3}{ }^{-}$to streams if hydrology were the primary driver of atmospheric $\mathrm{NO}_{3}{ }^{-}$export. That less atmospheric $\mathrm{NO}_{3}{ }^{-}$was exported from the Stage 1 watershed compared to the Stage 3 watershed despite similarities in discharge and atmospheric inputs suggests that the capacity for retention of atmospheric $\mathrm{NO}_{3}{ }^{-}$may be lower in the Stage 3 watershed. Indeed, the Stage 3 watershed served as a net source of $\mathrm{NO}_{3}{ }^{-}-\mathrm{N}$ relative to the amount of atmospheric $\mathrm{NO}_{3}{ }^{-}-\mathrm{N}$ deposited during 2010 (Table 4). However, quantification of the relative strengths of vegetation and soil $\mathrm{N}$ sinks in the two watersheds would be required to validate this speculation.

Although the higher proportions of atmospheric $\mathrm{NO}_{3}{ }^{-}$in streams during stormflow at Fernow are in agreement with the results of other studies that have examined atmospheric $\mathrm{NO}_{3}{ }^{-}$dynamics during hydrologic events (Burns and Kendall 2002; Sebestyen and others 2008, 2014; Pellerin and others 2012; Riha and others 2014), it is important to reiterate that the proportions of atmospheric $\mathrm{NO}_{3}{ }^{-}$we observed in streams are generally small throughout the year (range of median atmospheric $\mathrm{NO}_{3}{ }^{-}$proportions in all streams $=3$ to $39 \%$ ). Indeed, much larger discharges than those observed during the snowmelt event on 23 February were recorded from all of the watersheds during 2010 but these events occurred during the growing season, resulting in only marginal increases in the proportion of atmospheric $\mathrm{NO}_{3}{ }^{-}$in streams. Therefore, although hydrologic status is an important driver of atmospheric $\mathrm{NO}_{3}{ }^{-}$dynamics in these streams, extensive microbial $\mathrm{NO}_{3}{ }^{-}$production-particularly in the Stage 2 and 3 watersheds (Gilliam and others 2001) -also influences $\mathrm{NO}_{3}{ }^{-}$ source dynamics and total $\mathrm{NO}_{3}{ }^{-}-\mathrm{N}$ flux. 


\section{Seasonal Nitrate Isotope Dynamics}

Temporal patterns of triple $\mathrm{NO}_{3}{ }^{-}$isotopes provide insight into the biological $\mathrm{N}$ cycling dynamics of the study watersheds. A strongly seasonal pattern of stream $\delta^{15} \mathrm{~N}^{-\mathrm{NO}_{3}}{ }^{-}$values occurred in the Stage 1 , 2 , and 3 watersheds (Figure 3 ). The sharp increase in $\delta^{15} \mathrm{~N}-\mathrm{NO}_{3}{ }^{-}$values from early April through late August may have resulted from mass-dependent fractionations during nitrification and/or plant uptake. This increase was likely not due to denitrification, as a concomitant increase in $\delta^{18} \mathrm{O}_{-} \mathrm{NO}_{3}{ }^{-}$ values (characteristic of denitrification activity; Kendall 1998) did not occur in any of the streams. Although mineralization of organic $\mathrm{N}$ to $\mathrm{NH}_{4}{ }^{+}$does not result in large isotopic fractionations (Kendall 1998), oxidation of $\mathrm{NH}_{4}{ }^{+}$to $\mathrm{NO}_{3}{ }^{-}$can yield fractionations ranging from $-12 \%$ to $-29 \%$ (Shearer and Kohl 1986). Thus, as the ratio of net nitrification to net mineralization increases, the $\delta^{15} \mathrm{~N}-\mathrm{NO}_{3}{ }^{-}$ in soils should approach that of the original soil $\mathrm{NH}_{4}{ }^{+}$pool (Spoelstra and others 2007). Net nitrification rates in the Stage 2 and 3 watersheds are high during the growing season-reaching nearly $100 \%$ of net $\mathrm{N}$ mineralization rates-and soil $\mathrm{N}$ pools remain well above $0 \mathrm{~g} \quad \mathrm{NO}_{3}{ }^{-}-\mathrm{N} \mathrm{m}^{-2}$ throughout the year, indicating that microbial $\mathrm{NO}_{3}{ }^{-}-\mathrm{N}$ production exceeds plant uptake in these watersheds (Gilliam and others 2001). Preferential uptake of the lighter ${ }^{14} \mathrm{~N}$ isotope during the growing season may have yielded an isotopically-enriched residual soil $\mathrm{NO}_{3}{ }^{-}$pool (Högberg 1997; Kendall and others 2007; Templer and others 2007) from which stream $\mathrm{NO}_{3}{ }^{-}$was derived. Burns and Kendall (2002) reported $\delta^{15} \mathrm{~N}-\mathrm{NO}_{3}{ }^{-}$values ranging from +9 to $+16 \%$ in $\mathrm{O}$ horizon soils incubated at $22^{\circ} \mathrm{C}$ compared to $+1.5 \%$ in soils incubated at $4{ }^{\circ} \mathrm{C}$. The authors suggested that greater cycling of $\mathrm{N}$ through mineralization, nitrification, and immobilization processes may have yielded higher isotope values in the soils incubated at higher temperatures. Similar processes could have contributed to the enrichment in $\delta^{15} \mathrm{~N}$ values observed during the growing season in the Stage 1, 2, and 3 watersheds at Fernow. Although plant $\mathrm{N}$ demand decreases sharply at the end of the growing season, soil microbial processes such as nitrification can continue throughout the dormant season under an insulating snowpack (Campbell and others 2005). Decreased plant $\mathrm{N}$ demand at the end of the growing season and throughout the dormant season may similarly explain the lower $\delta^{15} \mathrm{~N}-\mathrm{NO}_{3}{ }^{-}$ values observed in streams during this time, as isotopic fractionation in the residual soil $\mathrm{NO}_{3}{ }^{-}$pool would have been less pronounced. The low $\delta^{15} \mathrm{~N}-$
$\mathrm{NO}_{3}{ }^{-}$values observed in the Stage 0 watershed $($ median $=+0.7 \%$ ) , their similarity to precipitation

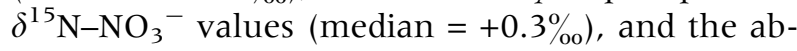
sence of seasonal isotopic enrichment in this watershed suggest that biologically mediated isotopic fractionations in the soil $\mathrm{NO}_{3}{ }^{-}$pool were less extensive in this watershed. This is in agreement with previous studies at Fernow that reported much lower rates of net nitrification in the Stage 0 watershed compared to the Stage 2 and 3 watersheds (Gilliam and others 2001; Kelly 2010).

In contrast to the seasonal enrichment of stream $\delta^{15} \mathrm{~N}^{-\mathrm{NO}_{3}}{ }^{-}$values in the Stage 1,2 , and 3 watersheds, stream $\delta^{18} \mathrm{O}_{-} \mathrm{NO}_{3}{ }^{-}$values were generally lower during the growing season in all watersheds (Figure 3; Table 3). The absence of a seasonal enrichment in stream $\delta^{18} \mathrm{O}-\mathrm{NO}_{3}{ }^{-}$values similar to that observed for $\delta^{15} \mathrm{~N}-\mathrm{NO}_{3}{ }^{-}$is unexpected, as both are subject to mass-dependent fractionation during biological processes and exhibit similar isotope effects during biological assimilation (Granger and others 2004; Deutsch and others 2009). It is possible that a seasonal enrichment in $\delta^{18} \mathrm{O}_{-} \mathrm{NO}_{3}{ }^{-}$values did occur similar to that observed in $\delta^{15} \mathrm{~N}-\mathrm{NO}_{3}{ }^{-}$values, but the effect was obscured by the concomitant decline in proportions of atmospheric $\mathrm{NO}_{3}{ }^{-}$in streams during the growing season. Due to the greater disparity in $\delta^{18} \mathrm{O}_{-} \mathrm{NO}_{3}{ }^{-}$values between atmospheric and microbial sources relative to the differences in $\delta^{15} \mathrm{~N}^{-\mathrm{NO}_{3}}{ }^{-}$values, it is possible that decreasing proportions of atmospheric $\mathrm{NO}_{3}{ }^{-}$in streams obscured any uptake-induced enrichment that may have occurred in $\delta^{18} \mathrm{O}_{-} \mathrm{NO}_{3}{ }^{-}$values. In addition, Burns and Kendall (2002) attributed greater variation in $\delta^{15} \mathrm{~N}$ values compared to $\delta^{18} \mathrm{O}$ values of $\mathrm{NO}_{3}{ }^{-}$ in a soil incubation experiment to differences in reaction pathways of nitrogen and oxygen during microbial $\mathrm{NO}_{3}{ }^{-}$processing. Whereas the original isotopic signature of $\mathrm{N}$ is partially preserved during $\mathrm{N}$ cycling processes, the isotopic composition of oxygen is reset with each nitrification cycle (Burns and Kendall 2002). The oxygen isotopic composition of microbial $\mathrm{NO}_{3}{ }^{-}$is reset through variable contributions of oxygen atoms from soil water and $\mathrm{O}_{2}$ in soils during nitrification (Buchwald and Casciotti 2010; Snider and others 2010); such exchange processes may have also contributed to the divergent seasonal patterns in $\delta^{15} \mathrm{~N}$ and $\delta^{18} \mathrm{O}$ of $\mathrm{NO}_{3}{ }^{-}$observed in the study watersheds.

In contrast to the seasonal pattern in $\delta^{18} \mathrm{O}-\mathrm{NO}_{3}{ }^{-}$ values, $\Delta^{17} \mathrm{O}-\mathrm{NO}_{3}{ }^{-}$values in weekly stream samples from the Stage 1, 2, and 3 watersheds were less variable from January to June (Figure 3), although significant seasonal differences were observed in the 
Stage 1 and 2 watersheds $(P<0.05$; Table 3$)$. Consequently, estimates of atmospheric $\mathrm{NO}_{3}{ }^{-}$proportions in streams calculated using $\delta^{18} \mathrm{O}-\mathrm{NO}_{3}{ }^{-}$were higher during the dormant season than proportions calculated using $\Delta^{17} \mathrm{O}-\mathrm{NO}_{3}{ }^{-}$values (Figure 4). The
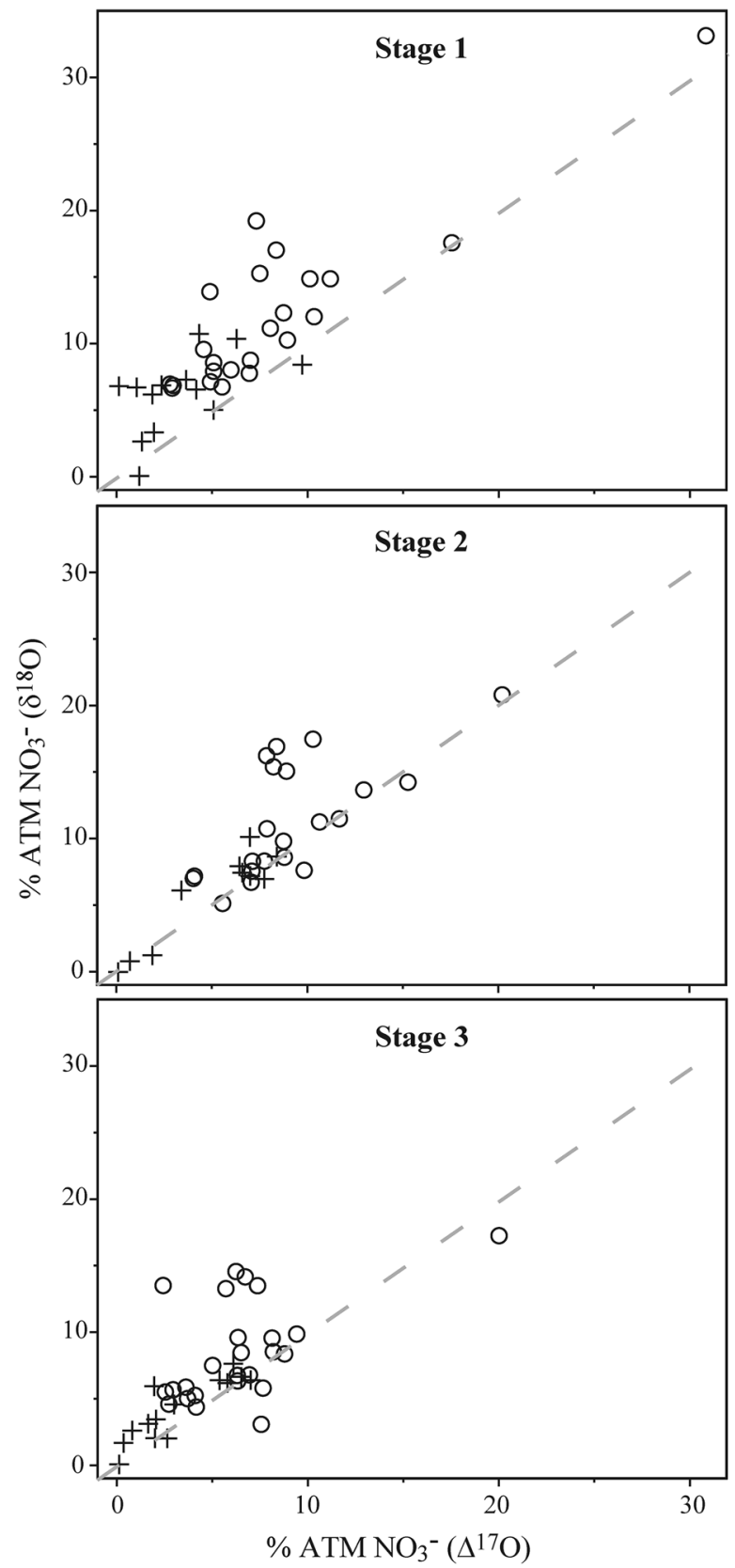

Figure 4. Estimated percent atmospheric $\mathrm{NO}^{-}$in weekly stream samples in hardwood watersheds at Fernow using $\Delta^{17} \mathrm{O}$ and $\delta^{18} \mathrm{O}$ of $\mathrm{NO}_{3}{ }^{-}$values in a two endmember isotope mixing model. $\delta^{18} \mathrm{O}$-based percentages over-estimate atmospheric $\mathrm{NO}_{3}{ }^{-}$contributions to streams during the dormant season (shown by circles), whereas percent estimates in growing season samples (shown by crosses) plot closer to the 1:1 line (shown by the dotted line) in all watersheds. greatest differences between $\delta^{18} \mathrm{O}$ - and $\Delta^{17} \mathrm{O}$-based estimates occurred in January and February, when

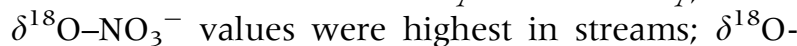
based estimates were up to $12 \%$ higher than $\Delta^{17} \mathrm{O}$ based estimates during this time. This may be attributable to seasonal differences in the $\delta^{18} \mathrm{O}$ values of water used by soil microbes during nitrification, as previously discussed. If seasonal variations in the oxygen isotopic composition of atmospheric $\mathrm{NO}_{3}{ }^{-}$ alone were responsible for the higher dormant season $\delta^{18} \mathrm{O}_{-} \mathrm{NO}_{3}{ }^{-}$values observed in streams, this would have also been reflected in the pattern of $\Delta^{17} \mathrm{O}-\mathrm{NO}_{3}{ }^{-}$ values of stream samples in all of the watersheds. That the $\delta^{18} \mathrm{O}$-based estimates of atmospheric $\mathrm{NO}_{3}{ }^{-}$ in streams are greater than those based on $\Delta^{17} \mathrm{O}$ $\mathrm{NO}_{3}{ }^{-}$and show a more distinctly seasonal pattern suggests that biologically mediated isotope fractionations resulted in the biased $\delta^{18} \mathrm{O}$-based estimates of atmospheric $\mathrm{NO}_{3}{ }^{-}$. Previous studies have also attributed higher $\delta^{18} \mathrm{O}$-based estimates of atmospheric $\mathrm{NO}_{3}{ }^{-}$in streams (compared to $\Delta^{17} \mathrm{O}-\mathrm{NO}_{3}{ }^{-}$-based estimates) to the influence of microbial activity (Riha and others 2014). These results demonstrate the advantage of using $\Delta^{17} \mathrm{O}-\mathrm{NO}_{3}{ }^{-}$over $\delta^{18} \mathrm{O}-\mathrm{NO}_{3}{ }^{-}$for more precise apportionment of atmospheric and biological $\mathrm{NO}_{3}{ }^{-}$contributions to streams.

\section{Conclusions}

Four nearly adjacent watersheds receiving identical atmospheric $\mathrm{NO}_{3}{ }^{-}$inputs but differing significantly in long-term patterns of stream $\mathrm{NO}_{3}{ }^{-}$export showed variable $\delta^{15} \mathrm{~N}, \delta^{18} \mathrm{O}$, and $\Delta^{17} \mathrm{O}$ dynamics of stream $\mathrm{NO}_{3}{ }^{-}$during 2010 . Our results indicate that:

(1) Atmospheric deposition can serve as the dominant source of $\mathrm{NO}_{3}^{-}$in some streams, particularly in watersheds characterized by low microbial nitrification rates and low stream $\mathrm{NO}_{3}^{-}$concentrations.

(2) Both flux-based and concentration-based estimates should be considered when evaluating $\mathrm{NO}_{3}^{-}$source contributions to streams, as the relative importance of atmospheric $\mathrm{NO}_{3}^{-}$may differ depending on which approach is used.

(3) Watershed hydrologic status influences the export of atmospheric $\mathrm{NO}_{3}^{-}$to streams, with greater proportions of atmospheric $\mathrm{NO}_{3}^{-}$in stormflow than baseflow.

(4) Nitrate source apportionments based on $\delta^{18} \mathrm{O}-$ $\mathrm{NO}_{3}^{-}$can over-estimate contributions from atmospheric deposition relative to $\Delta^{17} \mathrm{O}-\mathrm{NO}_{3}^{-}$based estimates. Because it is not affected by mass-dependent fractionations that commonly 
occur during biological processes, $\Delta^{17} \mathrm{O}-\mathrm{NO}_{3}^{-}$is a more robust and conservative tracer of atmospheric $\mathrm{NO}_{3}^{-}$than $\delta^{18} \mathrm{O}-\mathrm{NO}_{3}^{-}$.

\section{ACKNOWLEDGMENTS}

This work was supported by NSF Grant \#0910521 (to EME) and Agriculture and Food Research Initiative Grant \#2012-67011-19663 (to LAR) from the USDA National Institute of Food and Agriculture. We thank Christopher Cassidy for assistance with sample collection and processing, Katherine Redling for isotopic analysis, and the helpful comments of three anonymous reviewers during the preparation of this manuscript.

\section{REFERENCES}

Aber JD, Nadelhoffer KJ, Steudler P, Melillo JM. 1989. Nitrogen saturation in northern forest ecosystems. Bioscience 39:37886.

Aber J, Goodale CL, Ollinger S, Smith ML, Magill A, Martin ME, Hallet RA, Stoddard JL. 2003. Is nitrogen deposition altering the nitrogen status of northeastern forests? Bioscience 53:375-89.

Aber J, McDowell W, Nadelhoffer K, Magill A, Berntson G, Kamakea M, McNulty S, Currie W, Rustad L, Fernandez I. 1998. Nitrogen saturation in temperate forest ecosystems. Bioscience 48:921-34.

Adams MB, DeWalle DR, Peterjohn WT, Gilliam FS, Sharpe WE, Williard KW. 2006. Soil chemical response to experimental acidification treatments. In: The Fernow Watershed Acidification Study. Springer. pp 41-69.

Adams MB, Edwards PJ, Kochenderfer JN, Wood F. 2003. Fifty years of watershed research on the Fernow Experimental Forest, WV: effects of forest management and air pollution in hardwood forests. First interagency conference on research in the watersheds. Benson: USDA-ARS. p 391-6.

Adams MB, Knoepp JD, Webster JR. 2014. Inorganic nitrogen retention by watersheds at Fernow Experimental Forest and Coweeta Hydrologic Laboratory. Soil Sci Soc Am J 78:S84-94.

Adams MB, Kochenderfer JN, Edwards PJ. 2007. The Fernow watershed acidification study: ecosystem acidification, nitrogen saturation and base cation leaching. Water Air Soil Pollut Focus 7:267-73.

Barnes RT, Raymond PA, Casciotti KL. 2008. Dual isotope analyses indicate efficient processing of atmospheric nitrate by forested watersheds in the northeastern US. Biogeochemistry 90:15-27.

Buchwald C, Casciotti KL. 2010. Oxygen isotopic fractionation and exchange during bacterial nitrite oxidation. Limnol Oceanogr 55:1064-74.

Buldgen P, Dubois D, Remacle J. 1983. Principal component analysis applied to nutrient balances in organic layers of beech and spruce forests. Soil Biol Biochem 15:511-18.

Burns DA, Kendall C. 2002. Analysis of $\delta^{15} \mathrm{~N}$ and $\delta^{18} \mathrm{O}$ to differentiate $\mathrm{NO}_{3}$-sources in runoff at two watersheds in the Catskill Mountains of New York. Water Resour Res 38:9-1.
Campbell JL, Mitchell MJ, Groffman PM, Christenson LM, Hardy JP. 2005. Winter in northeastern North America: a critical period for ecological processes. Front Ecol Environ 3:314-22.

Casciotti KL, Sigman DM, Hastings MG, Böhlke JK, Hilkert A. 2002. Measurement of the oxygen isotopic composition of nitrate in seawater and freshwater using the denitrifier method. Anal Chem 74:4905-12.

Christenson LM, Lovett GM, Weathers KC, Arthur MA. 2009. The influence of tree species, nitrogen fertilization, and soil C to $\mathrm{N}$ ratio on gross soil nitrogen transformations. Soil Sci Soc Am J 73:638-46.

Christ MJ, Peterjohn WT, Cumming JR, Adams MB. 2002. Nitrification potentials and landscape, soil and vegetation characteristics in two central Appalachian watersheds differing in $\mathrm{NO}_{3}{ }^{-}$export. For Ecol Manage 159:145-58.

Coplen TB, Böhlke JK, Casciotti KL. 2004. Using dual-bacterial denitrification to improve $\delta^{15} \mathrm{~N}$ determinations of nitrates containing mass-independent ${ }^{17} \mathrm{O}$. Rapid Commun Mass Spectrom 18:245-50.

Creed IF, Band LE. 1998. Export of nitrogen from catchments within a temperate forest: evidence for a unifying mechanism regulated by variable source area dynamics. Water Resour Res 34:3105-20.

Deutsch B, Voss M, Fischer H. 2009. Nitrogen transformation processes in the Elbe River: distinguishing between assimilation and denitrification by means of stable isotope ratios in nitrate. Aquat Sci 71:228-37.

Durka W, Schulze ED, Gebauer G, Voerkellust S. 1994. Effects of forest decline on uptake and leaching of deposited nitrate determined from ${ }^{15} \mathrm{~N}$ and ${ }^{18} 0$ measurements. Nature 372:22.

Fernandez IJ, Adams MB, SanClements MD, Norton SA. 2010. Comparing decadal responses of whole-watershed manipulations at the Bear Brook and Fernow experiments. Environ Monit Assess 171:149-61.

Galloway JN, Aber JD, Erisman JW, Seitzinger SP, Howarth RW, Cowling EB, Cosby BJ. 2003. The nitrogen cascade. Bioscience 53:341-56.

Gilliam FS, Yurish BM, Adams MB. 2001. Temporal and spatial variation of nitrogen transformations in nitrogen-saturated soils of a central Appalachian hardwood forest. Can J For Res $31: 1768-85$.

Goodale CL, Thomas SA, Fredriksen G, Elliott EM, Flinn KM, Butler TJ, Walter MT. 2009. Unusual seasonal patterns and inferred processes of nitrogen retention in forested headwaters of the Upper Susquehanna River. Biogeochemistry 93:197-218.

Granger J, Sigman DM, Needoba JA, Harrison PJ. 2004. Coupled nitrogen and oxygen isotope fractionation of nitrate during assimilation by cultures of marine phytoplankton. Limnol Oceanogr 49:1763-73.

Högberg P. 1997. Tansley Review No. $95{ }^{15} \mathrm{~N}$ natural abundance in soil-plant systems. New Phytol 137:179-203.

Kaiser J, Hastings MG, Houlton BZ, Röckmann T, Sigman DM. 2007. Triple oxygen isotope analysis of nitrate using the denitrifier method and thermal decomposition of $\mathrm{N}_{2} \mathrm{O}$. Anal Chem 79:599-607.

Kelly CN. 2010. Carbon and nitrogen cycling in watersheds of contrasting vegetation types in the Fernow Experimental Forest, West Virginia. Doctoral dissertation, Virginia Polytechnic Institute and State University.

Kelly C, Schoenholtz S, Adams M. 2011. Soil properties associated with net nitrification following watershed conversion 
from Appalachian hardwoods to Norway spruce. Plant Soil 344:361-76.

Kendall C. 1998. Tracing nitrogen sources and cycling in catchments. In: Kendall C, McDonnell JJ, Eds. Isotope Tracers in Catchment Hydrology. Amsterdam: Elsevier. p 519-76.

Kendall C, Elliott EM, Wankel SD. 2007. Tracing anthropogenic inputs of nitrogen to ecosystems. In: Michener R, Lajtha K, Eds. Stable Isotopes in Ecology and Environmental Science, Vol. 2. Oxford: Blackwell Publishing. p 375-449.

Kochenderfer JN. 2007. Fernow and the Appalachian hardwood region. In: Adams MB, DeWalle DR, Hom JR, Eds. The Fernow Watershed Acidification Study. Dordrecht, The Netherlands: Springer. p 17-39.

Lovett G, Goodale C. 2011. A new conceptual model of nitrogen saturation based on experimental nitrogen addition to an oak forest. Ecosystems 14:615-31.

Lovett GM, Weathers KC, Arthur MA. 2002. Control of nitrogen loss from forested watersheds by soil carbon: nitrogen ratio and tree species composition. Ecosystems 5:0712-18.

Lovett GM, Weathers KC, Arthur MA, Schultz JC. 2004. Nitrogen cycling in a northern hardwood forest: do species matter? Biogeochemistry 67:289-308.

Michalski G, Meixner T, Fenn M, Hernandez L, Sirulnik A, Allen E, Thiemens M. 2004. Tracing atmospheric nitrate deposition in a complex semiarid ecosystem using $\Delta^{17} \mathrm{O}$. Environ Sci Technol 38:2175-81.

Pardo LH, Kendall C, Pett-Ridge J, Chang CCY. 2004. Evaluating the source of streamwater nitrate using $\delta^{15} \mathrm{~N}$ and $\delta^{18} \mathrm{O}$ in nitrate in two watersheds in New Hampshire, USA. Hydrol Process 18:2699-712.

Pellerin BA, Saraceno JF, Shanley JB, Sebestyen SD, Aiken GR, Wollheim WM, Bergamaschi BA. 2012. Taking the pulse of snowmelt: in situ sensors reveal seasonal, event and diurnal patterns of nitrate and dissolved organic matter variability in an upland forest stream. Biogeochemistry 108:183-98.

Peterjohn WT, Adams MB, Gilliam FS. 1996. Symptoms of nitrogen saturation in two central Appalachian hardwood forest ecosystems. Biogeochemistry 35:507-22.

Prescott CE, Grayston SJ. 2013. Tree species influence on microbial communities in litter and soil: current knowledge and research needs. For Ecol Manage 309:19-27.

Reinhart KG, Eschner A, Trimble GR. 1963. Effect on streamflow of four forest practices in the mountains of West Virginia. Research Paper NE-1. Upper Darby, PA: US Department of Agriculture, Forest Service, Northeastern Forest Experiment Station. 79 p.

Riha K, Michalski G, Gallo E, Lohse K, Brooks P, Meixner T. 2014. High atmospheric nitrate inputs and nitrogen turnover in semi-arid urban catchments. Ecosystems 1-17.
Ross DS, Lawrence GB, Fredriksen G. 2004. Mineralization and nitrification patterns at eight northeastern USA forested research sites. For Ecol Manage 188:317-35.

SAS Institute, Inc. 2011. SAS/STAT user's guide: Statistics, Release 9.3 edition. Cary, NC.: SAS Institute, Inc.

Sebestyen SD, Boyer EW, Shanley JB, Kendall C, Doctor DH, Aiken GR, Ohte N. 2008. Sources, transformations, and hydrological processes that control stream nitrate and dissolved organic matter concentrations during snowmelt in an upland forest. Water Resour Res 44:W12410.

Sebestyen SD, Shanley JB, Boyer EW, Kendall C, Doctor DH. 2014. Coupled hydrological and biogeochemical processes controlling variability of nitrogen species in streamflow during autumn in an upland forest. Water Resour Res 50:1569-91.

Shearer G, Kohl DH. 1986. $\mathrm{N}_{2}$-fixation in field settings: estimations based on natural ${ }^{15} \mathrm{~N}$ abundance. Funct Plant Biol 13:699756.

Sigman DM, Casciotti KL, Andreani M, Barford C, Galanter M, Böhlke JK. 2001. A bacterial method for the nitrogen isotopic analysis of nitrate in seawater and freshwater. Anal Chem 73:4145-53.

Snider DM, Spoelstra J, Schiff SL, Venkiteswaran JJ. 2010. Stable oxygen isotope ratios of nitrate produced from nitrification: ${ }^{18} \mathrm{O}$-labeled water incubations of agricultural and temperate forest soils. Environ Sci Technol 44:5358-64.

Spoelstra J, Schiff SL, Hazlett PW, Jeffries DS, Semkin RG. 2007. The isotopic composition of nitrate produced from nitrification in a hardwood forest floor. Geochim Cosmochim Acta 71:3757-71.

Stoddard JL. 1994. Long-term changes in watershed retention of nitrogen. Its causes and aquatic consequences. In: Baker L, Ed. Environmental Chemistry of Lakes and Reservoirs. Washington, DC: American Chemical Society. p 223-84.

Templer PH, Arthur MA, Lovett GM, Weathers KC. 2007. Plant and soil natural abundance $\delta^{15} \mathrm{~N}$ : indicators of relative rates of nitrogen cycling in temperate forest ecosystems. Oecologia 153:399-406.

Templer PH, Lovett GM, Weathers KC, Findlay SE, Dawson TE. 2005. Influence of tree species on forest nitrogen retention in the Catskill Mountains, New York, USA. Ecosystems 8:1-16.

Tiner RW. 1993. The primary indicators method-a practical approach to wetland recognition and delineation in the United States. Wetlands 13:50-64.

U.S. Environmental Protection Agency. 2014. U.S. Environmental Protection Agency Clean Air Markets Division Clean Air Status and Trends Network (CASTNET). www.epa.gov/ castnet. Last accessed 21/10/2014.

Williard KW, DeWalle DR, Edwards PJ, Sharpe WE. 2001. ${ }^{18} \mathrm{O}$ isotopic separation of stream nitrate sources in mid-Appalachian forested watersheds. J. Hydrol 252:174-88. 